\title{
2. BLACK SEA STRATIGRAPHY
}

David A. Ross, Woods Hole Oceanographic Institution, Woods Hole, Massachusetts

\begin{abstract}
This paper presents some details of the stratigraphic nomenclature of Black Sea sediments and short summaries of the relevant paleonotological studies performed on sediments collected during Leg 42B. Based on these studies, a consistent and generally acceptable stratigraphy for the drilled Black Sea sediment cannot be established at this time.
\end{abstract}

\section{INTRODUCTION}

One of the more complex problems emerging from the Black Sea drilling has been the establishment of a uniform and consistent stratigraphy for the sedimentary units. There are several reasons for the complexity, first of which is the general shortage of definitive paleontological age markers. This is due, among other things, to the relatively short period of geological time the cores cover, to the rapidly changing environmental conditions that often leave a more distinctive mark than evolution on the faunal and floral composition, to the frequent lack of preservation of the fauna and flora, to the lack of taxonomic knowledge of many of the forms, and to reworking and incorporation of older forms into the sediments. Some of these points are discussed further in later sections.

The second major reason for the complexity in establishing a uniform stratigraphy is the general lack of agreement on correlation and time zonation of the sedimentary units. Some authors have used the European Alpine classification; others have used Soviet classifications based on the Black Sea, Caspian, or Caucasus regions and still others have devised new classifications of their own. The latter, in a large part, has resulted from major differences of opinion among scientists who tried to relate their observed sedimentary units to a geologic interpretation of the facies and then tie this interpretation to a stratigraphic scheme. This difference of opinion particularly applies to those who emphasized Sites 379 and 381, as compared to those who worked principally on Site 380 . Some scientists unfortunately renumbered or reorganized the original sedimentary designation (i.e., units) of the samples they studied.

As one of the Chief Scientists, I waited for the paleontologists to give me the gospel for the Black Sea. It never came in the definitive form I anticipated, for all or some of the above-mentioned reasons. I had planned to compare the conflicting views and make a scientific, or if that was not possible, a pontifical decision as to

\footnotetext{
${ }^{3}$ Contribution 3811, Woods Hole Oceanographic Institution.
}

the correct stratigraphy to use. This plan, which seemed se easy while on the secure decks of Glomar Challenger, turned out to be nearly impossible upon return to the real world. In this manuscript, I have included tables depicting some classification schemes, and have attempted to indicate what seem to be good correlations as well as those areas where complication between sites exists. In the summary article at the end of this volume I have attempted to synthesize the general geological history of the Black Sea during the period covered by the drilling results of Leg 42B. The careful reader is forwarned: "Caveat emptor."

\section{GENERAL STRATIGRAPHIC SCHEMES FOR BLACK SEA SEDIMENTS}

Several stratigraphic schemes have been devised for the Black Sea region, and these can be generally correlated with European and U.S. terminology. Tables $1 \mathrm{~A}$ and $1 \mathrm{~B}$ are derived from various compilations, and although they might not represent the latest and most definitive word on the stratigraphy of the area, they should be useful for most purposes. Table $1 \mathrm{~A}$ is generally more consistent with European nomenclature, whereas Table 1B from Koreneva and Kartashova (this volume) is more typical of Soviet terminology.

Prior to the cruise of Glomar Challenger the surficial Black Sea sediments had been sampled (by cores) and studied by numerous investigators. Within the deeper parts of the basin, three main stratigraphic units have been recognized, dated, and classified (Degens and Ross, 1974, and articles therein). The stratigraphic position of these units (Unit 1, at the top, a $30-\mathrm{cm}$ thick coccolith ooze; Unit 2, a 30-cm-thick sapropel; Unit 3, at the base, a terrigenous mud not completely penetrated) seems fairly clear (see Table 2 ). These three units are correlative with sediments from Site 379, 380, and 381 (Table 3).

Prior to discussing the stratigraphy of older sediments, a brief summary of the paleontological work is appropriate. It should be emphasized that the paleontological studies were generally more useful in indicating environmental conditions than in indicating 
TABLE 1A

Pleistocene Correlation of

European, North American, and Black Sea Areas ${ }^{a}$

\begin{tabular}{|c|c|c|c|c|}
\hline Northern Europe & $\begin{array}{c}\text { Central } \\
\text { Alpine Europe }\end{array}$ & North America & Black Sea & \\
\hline Post Glacial & & & $\begin{array}{l}\text { New Black Sea } \\
\text { Old Black Sea } \\
\text { (See Table 2) }\end{array}$ & Holocene \\
\hline $\begin{array}{l}\text { Weichselian } \\
\text { (glacial) }\end{array}$ & Würm & & $\begin{array}{l}\text { New Euxinian } \\
\text { (Novo-Euxinian) }\end{array}$ & $\mathbf{P}$ \\
\hline$\underset{\text { (interglacial) }}{\text { Eemian }}$ & Riss/Würm & Wisconsin & Karangat & 1 \\
\hline $\begin{array}{c}\text { Saalian } \\
\text { (Glacial) }\end{array}$ & Riss & & Post Uzunlar ${ }^{b}$ & e \\
\hline $\begin{array}{c}\text { Holsteinian } \\
\text { (Interglacial) }\end{array}$ & Mindel/Riss & Sangamonian & Uzunlar ${ }^{\mathrm{b}}$ & $s$ \\
\hline $\begin{array}{l}\text { Elsterian } \\
\text { (glacial) }\end{array}$ & Mindel & Illinoian & Old Euxinian ${ }^{b}$ & $\mathrm{t}$ \\
\hline $\begin{array}{c}\text { Cromerian } \\
\text { (Interglacial) }\end{array}$ & Gunz/Minitel & Yarmouthian & Post Chauda ${ }^{b, c}$ & o \\
\hline \multirow[t]{2}{*}{$\begin{array}{c}\text { Menapian } \\
\text { (Glacial) }\end{array}$} & Günz & & & c \\
\hline & & Kansan & & e \\
\hline Waalian & $\begin{array}{l}\text { Danube/Günz } \\
\text { (Interglacial) }\end{array}$ & & Chaudac & $\mathrm{n}$ \\
\hline Eburion & Danube & Nebraskan & & e \\
\hline Tiglian & $\begin{array}{l}\text { Biber/Danube } \\
\text { (Interglacial) }\end{array}$ & & $\begin{array}{c}\text { Gurian } \\
\text { Akcagyl }\end{array}$ & \\
\hline Pretiglian & Biber & & & \\
\hline
\end{tabular}

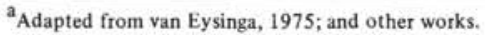

${ }^{b}$ Jouse and Mukhina, this volume, correlate Uzunlat to the Riss, Drevne-Euxinian to the Mindel/Riss, and Chauda to the Mindel. Schroeder correlates the Cromerian to the old Euxinian and the Menapian to the Post Chauda.

${ }^{\mathrm{c}}$ Some disagreement here, because some authors prefer the use of Chauda with Cromerian.

the age of the sediment. The major paleontological findings relevant to the Black Sea biostratigraphy are described below.

\section{Ostracodes}

A wide variety of forms were noted, many of which have been found in stratigraphic sections from surrounding basins (Olteanu, this volume), but no Pleistocene stratigraphic division was possible. Benson (this volume), looking at a small number of samples, noted that the ostracodes were modern relicts of late Miocene and Pliocene faunas, whose species underwent little change during the Pleistocene. He thought the ostracodes could eventually be of some stratigraphic utility when their morphology is better understood.

\section{Coccoliths}

Most of the coccoliths found by Percival (this volume) were reworked. The indigenous species could be divided into three different types:

(1) An Emiliania huxleyi flora found only in new surface cores from Site 379 and of late Quaternary age.

(2) A Gephyrocapsa caribbeanica flora present in a 100 -meter-thick section at top of Sites 379 and 380 and of Quaternary age.

(3) A Braarudosphaera bigelowi flora found in thin horizons at all three sites, ranging in age from Jurassic to Recent.

None of these were of any significant stratigraphic use, except that types 1 and 3 indicate brackish marine conditions, whereas 2 is more indicative of normal marine environments. Bukry, in 1974, examined the piston cores collected by the 1969 Atlantis II expedition to the Black Sea, and with the exception of the uppermost sedimentary unit (Unit I), also found mainly reworked forms.

\section{Foraminifers}

Only about one-third of the over 300 samples examined contained foraminifers; most of them were benthic (Gheorghian, this volume). The same author concludes that the bulk of the foraminifers migrated into the area from the Mediterranean and adapted to the reduced salinity in the Black Sea. The general absence of planktonic forms is surprising. Gheorghian concluded that all three sites penetrated Quaternary, Pliocene, and upper Miocene sediments (actually he probably meant only Sites 380 and 381 , since no other workers have found Pliocene or Miocene material from Site 379).

\section{Spores and Pollen}

Spores and pollen were probably the most extensively studied paleontological group (Traverse, this volume; Koreneva and Kartashova, this volume). Essentially all the samples studied contained abundant spores and pollen. Traverse also noted a bizarre dinoflagellate that flourished when the water freshened. He developed a Steppe-Forest Index for all three sites using a ratio of appropriate species of spores and pollen, that serve as a climatic indicator. A high ratio indicates more cool/dry conditions (or Steppe conditions). The modern-day samples have a low ratio of $10 \%$, indicative of warm/wet or Forest conditions. Another ratio called the Marine-Influence Index, compares the amounts of dinoflagellates and acritarchs to dinoflagellates, acritarchs and total pollen; low values suggest non-marine conditions.

Traverse (this volume) used Site 380 as a standard for comparison to Sites 379 and 381. Three cool or Steppe periods termed "Alpha," "Beta," and "Gamma" were detected at Site 380 . These indicate times when the Black Sea drainage area was dominated by plants adapted to conditions cooler and drier than today. Four warm periods were detected: "Celia," "Betty," "Anna," and "Pre-Alpha." These seven names were chosen to clearly avoid any confusion with pre-existing Pleistocene stratigraphy. At this time there is no definitive correlation of these periods to a specific glacial or interglacial period. However, some suggested correlations presented later are based on plaeontological evidence (Tables 5 and 7) or on estimates of sedimentation rates and other criteria (Table 8). Traverse's data from the three sites are summarized in Table 4. Note that the section for Site 381 is relatively incomplete compared to Site 380 .

The palynological studies of Koreneva and Kartashova (this volume) are also of considerable importance (they studied only Sites 379 and 380). They suggest that the lower part of Hole 380A (Cores 33 to 80 ) is of Pliocene age, but they admit that the boundary is hard to determine. Traverse suggested that the boundary might occur below Core 60 in Hole 380A, where Artemisia is absent (this form is more typical of the colder drier Pleistocene climate). Cores 12-32 of Hole $380 \mathrm{~A}$ were found by Koreneva and Kartashova to 
TABLE IB

Pleistocene Correlation of the B lack Sea Chronostratigraphic Units With That of Europe

(from Koroneva and Kastaskova, this volume)

\begin{tabular}{|c|c|c|c|c|c|c|c|}
\hline \multirow{4}{*}{ E } & \multirow{4}{*}{ 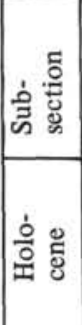 } & \multirow{4}{*}{ 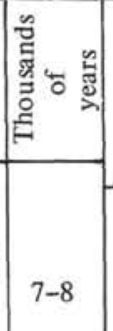 } & \multirow{4}{*}{$\begin{array}{c}\text { Alpinian } \\
\text { Stratigraphic } \\
\text { Scale }\end{array}$} & \multirow{4}{*}{$\begin{array}{l}\text { Mediterranean } \\
\text { Sea } \\
\text { Flandrian }\end{array}$} & \multicolumn{3}{|c|}{ Subdivision of the Pleistocene in USSR } \\
\hline & & & & & \multirow{3}{*}{$\begin{array}{c}\begin{array}{r}\text { European Part } \\
\text { of the USSR }\end{array} \\
\text { Holocene }\end{array}$} & \multicolumn{2}{|c|}{ Black Sea } \\
\hline & & & & & & Black & Late \\
\hline & & & & & & Sea & Early \\
\hline & \multirow{4}{*}{ 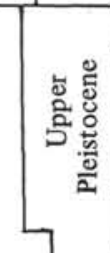 } & 23 & \multirow{3}{*}{ Würm } & \multirow{3}{*}{$\begin{array}{l}\text { Grimaldian } \\
\text { (Regression) }\end{array}$} & Ostashkian & \multicolumn{2}{|c|}{ Novo-Euxinian } \\
\hline & & 45 & & & Mologo-Schexnian & \multicolumn{2}{|c|}{ Surdzh (?) } \\
\hline & & 65 & & & Kalinian & \multicolumn{2}{|c|}{ Post-Karangat } \\
\hline & & $\begin{array}{l}90- \\
100\end{array}$ & Riss-Würm & Neotirrhenian & Miculian & & ingat \\
\hline \multirow{10}{*}{ 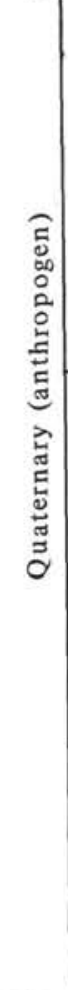 } & ఝ్ & & \multirow{4}{*}{ Riss } & Regression & Moskovian & & ssion \\
\hline & $\frac{\sqrt{2}}{0}$ & & & & Odintsovian & & \\
\hline & 总 & \multirow{2}{*}{230} & & \multirow{2}{*}{ Regression (?) } & \multirow{2}{*}{ Dneprian } & \multicolumn{2}{|c|}{$\begin{array}{l}\text { Late Drevne- } \\
\text { Euxinian }\end{array}$} \\
\hline & & & & & & \multicolumn{2}{|c|}{ Regression } \\
\hline & & & \multirow{2}{*}{ Mindel-Riss } & \multirow{2}{*}{ Paleotyrrhenian } & \multirow{2}{*}{ Likhvinian } & \multicolumn{2}{|c|}{ Paleouzumlar } \\
\hline & \multirow{3}{*}{ 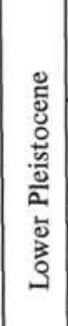 } & 300 & & & & \multicolumn{2}{|c|}{ Early Drevne Euxin } \\
\hline & & & Mindel & Regression & Okan & \multicolumn{2}{|c|}{ Regression } \\
\hline & & 700 & Günz-Mindel & Sicilian & \multirow{3}{*}{$\begin{array}{l}\text { Belavezhskian } \\
\text { Stages }\end{array}$} & & \\
\hline & \multirow[t]{2}{*}{ 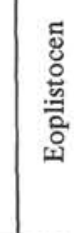 } & & Günz & Emilian & & \multirow{2}{*}{\multicolumn{2}{|c|}{ Gurian }} \\
\hline & & & Danou- Günz-Danau & Calabrian & & & \\
\hline \multicolumn{3}{|c|}{ Pliocene } & Pliocene & Astian & Pliocene & \multicolumn{2}{|c|}{ Kujalnik } \\
\hline
\end{tabular}

be of Gurian age (see Table 5), whereas Cores 7-11 $(380 \mathrm{~A})$ are Chauda in age. If the correlation is correct, it suggests that the "Alpha" glacial period correlates with the Tiglian or Pretiglian, an age somewhat older than others have suggested. They note that Cores 13-15, Hole 379A, and Cores 9-11, Hole 380, are part of the Postuzunlarian layers (Saalian). This implies that the "Gamma" glacial period is correlative to the Riss. Likewise, the "Beta" may correlate with the Mindel or Elsterian.

\section{Diatoms}

Diatoms were studied in considerable detail by Schrader (this volume) and Jousé and Mukhina (this volume). These plants are of considerable use because of their responsiveness to environmental changes.

For Site 379 both studies note the absence of diatoms below Core 29. On one hand, Jousé and Mukhina record that the marine species from this site were euryhaline forms living in waters of lower salinity, whereas the fresh-water species were halophile forms that could tolerate some degree of salinity. They divide the diatoms on this site into four zones:

1) $7, \mathrm{CC}$ to $8, \mathrm{CC}$-fresh-water assemblage with some brackish water and sporadic marine forms-relatively cold-water species.

2) $9-2$ to 10, CC-marine, moderately warm-water assemblage with no fresh water forms. 
TABLE 2

Suggested Relationships Between Black Sea Deep-Water Sediment Stratigraphy and Local Black Sea Stratigraphic Sections Based Primarily Upon In-Shore Molluscan Faunas

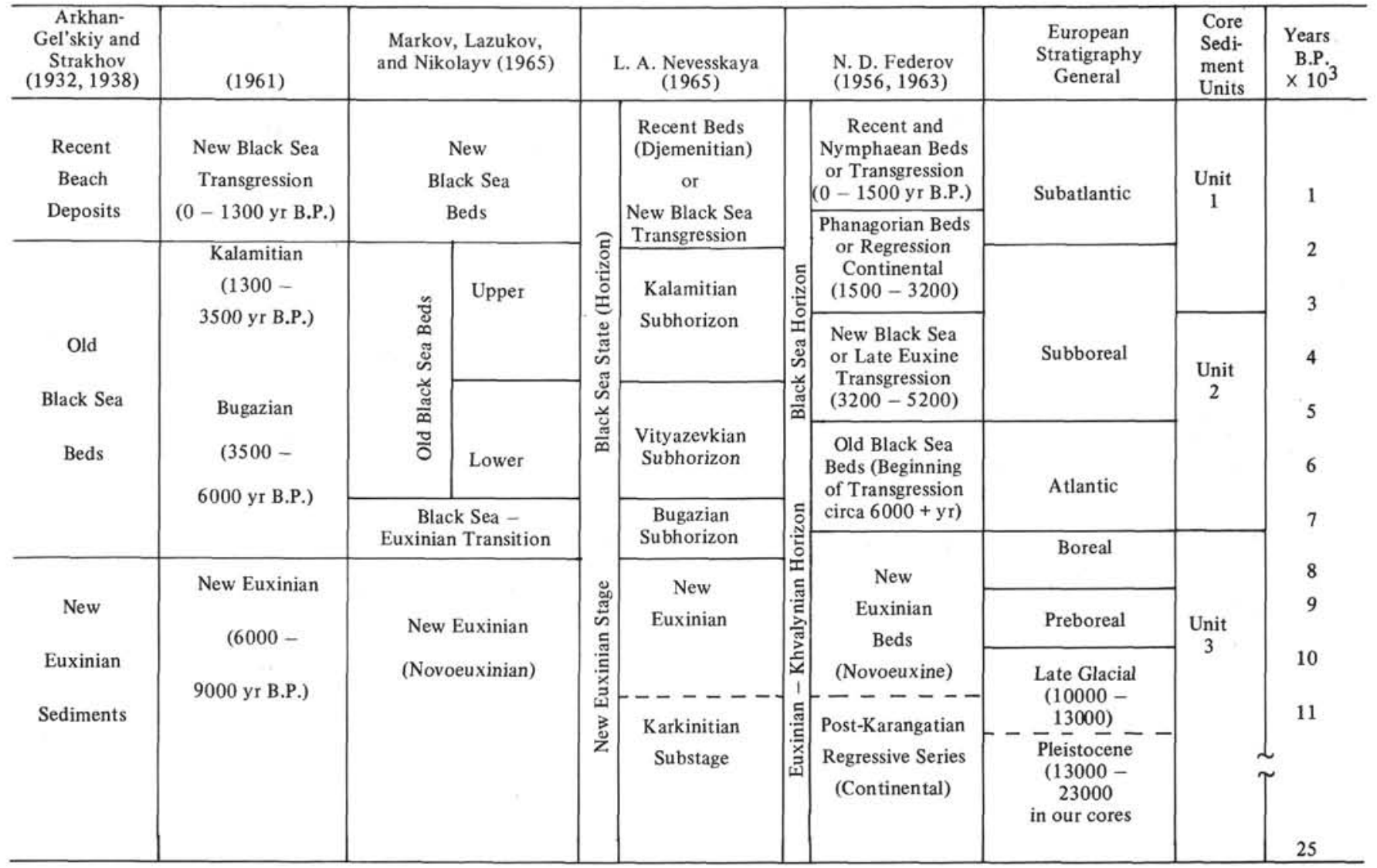

Note: Figures in parentheses are estimated ages that were given by the author(s) whose name appears at the top of the table (from Wall and Dale, 1974).

3) 17-1 to 25-1-brackish water and fresh-water halophile species assemblage typical of fresh-water lakes.

4) $25-2$ to $29-4$-marine and relatively cold-water assemblage.

They date these units as Novoeuxinian, Karangat, Uzunlar, and Drevne-euxiniar, respectively. Schrader, on the other hand (and it should be noted that both workers did not study the same samples nor have

TABLE 3

Stratigraphic Correlation of Surface Sediments Collected by Previous Coring, With Surface Sediments Collected During Leg 42B Drilling

\begin{tabular}{cccc}
\hline Cored & Hole & Site & Site \\
Sediments & $379 \mathrm{~A}$ & 380 & 380 \\
\hline & & & \\
(Degens and Ross, 1974) & & & \\
Unit I & $1^{\mathrm{a}}$ & $\mathrm{Ia}^{\mathrm{a}}$ & $\mathrm{b}$ \\
Unit II & $2^{\mathrm{a}}$ & $\mathrm{Ib}$ & $\mathrm{b}$ \\
Unit III & 3 & $\mathrm{Ic}$ & 1 \\
\hline
\end{tabular}

${ }^{a}$ Not absolutely drilled, but inferred either from patches of material in recovered sediments, or from previous studies.

${ }^{b}$ Apparently much of the upper part of the sediments found at Hole 379A and Site 380 are missing from Site 381 . sufficient and continuous material to make the detailed study they probably wanted to do), noted basically four marine periods from Site 379, occurring in his Unit II (Cores 8-11), Unit IV (Cores 12-24), and two in Unit V (Cores 24-29). The evaluation by Schrader, and Jousé and Mukhina, of the environmental conditions for Site 379 , is essentially the same. They use different

TABLE 4

Palynological Correlation Between the Three Black Sea Sites as Determined by Ratios of Spores and Pollen (see Traverse, this volume)

\begin{tabular}{|c|c|c|c|}
\hline $\begin{array}{l}\text { Steppe-Forest } \\
\text { Index }\end{array}$ & Position at Site $379^{a}$ & Position at Site $380^{a}$ & Position at Site $381^{a}$ \\
\hline $\begin{array}{c}\text { Celia } \\
\text { (Forest) }\end{array}$ & Cores 1-9 & Cores 1-6 $(380)$ & Missing \\
\hline $\begin{array}{l}\text { Gamma } \\
\text { (Steppe) }\end{array}$ & Cores $10-21$ & Cọres 7-12 & Cores 1-6 \\
\hline $\begin{array}{c}\text { Betty } \\
\text { (Forest) }\end{array}$ & Cores $24-34(?)$ & Cores $13-20$ & Cores 7-10 (?) \\
\hline $\begin{array}{c}\text { Beta } \\
\text { (Steppe) }\end{array}$ & Cores $35-41$ (?) & Cores $21-28$ & Probably missing \\
\hline $\begin{array}{c}\text { Anna } \\
\text { (Forest) }\end{array}$ & Cores 42-55 & Cores $1-13(380 \mathrm{~A})$ & Probably missing \\
\hline $\begin{array}{c}\text { Alpha } \\
\text { (Steppe) }\end{array}$ & Cores 53-61 & Cores $14-35$ & Cores 11-27 \\
\hline Pre-Alpha & Cores 62-68 (?) & Cores $36-80$ & Core 28-? \\
\hline
\end{tabular}

${ }^{\mathrm{a}}$ Based on extrapolation from data presented in site reports; correlations are based mainly on simple stratigraphic succession, rather than occurrence of key species, and thus could be in error. 
TABLE 5

Correlations as Determined by Spore and Pollen Studies of Koreneva and Kartashova (this volume)

\begin{tabular}{|c|c|c|c|c|}
\hline & Hole 379 & Hole 380 & Hole $380 \mathrm{~A}$ & Remarks \\
\hline New Euxinian & top & top & & Temperate, cool \\
\hline Surozhskie (?) & - & Core 2 & & $\begin{array}{l}\text { Warming and moistening } \\
\text { of climate }\end{array}$ \\
\hline Post-Karangatian & Cores 4-10.5 & Cores 3-6 (?) & & $\begin{array}{l}\text { Alternation of forest } \\
\text { and steppe vegetation }\end{array}$ \\
\hline Karangatian & Cores 10.6-12.1 & Core 7 & & Warm, temperate flora \\
\hline Postuzunlarian & Cores $13-15$ & Cores 9-11 & & Cold \\
\hline Uzunlarian & Cores $16-20$ & Cores $11 \mathrm{cc}-19(?)$ & & Temperate-warm \\
\hline $\begin{array}{l}\text { Dreve-euxinian } \\
\quad \text { (late) }\end{array}$ & Cores $21-42$ & Cores $19(?)-32$ & & Temperate-cold \\
\hline $\begin{array}{c}\text { Paleouzunlarian- } \\
\text { Dreve-euxinian } \\
\text { (early) }\end{array}$ & Cores 43-54 & Cores 33-37 & & Temperate-warm \\
\hline $\begin{array}{l}\text { Regressive } \\
\text { layers }\end{array}$ & Cores 55-66 & Cores $38-40$ & Cores 2-7 & Temperate-cold \\
\hline Chauda & Cores $67-68$ & & Cores $7-11$ & Temperate-warm \\
\hline Gurian & & & Cores $12-32$ & Temperate-cold \\
\hline Pliocene & & & Cores $33-80$ & $\begin{array}{l}\text { Temperate-warm } \\
\text { Subtropical }\end{array}$ \\
\hline
\end{tabular}

numbering systems for the sedimentologic units, but correlation between their data is possible by using core numbers.

For Site 380 Schrader describes nine units, with three marine episodes in Site 380 (also three small excursions), and also three in Hole 380A (the upper two of which are similar to the lower two of Site 380).Correlations between the two holes, generally accepted by most workers involved with Leg 42B, are:

Hole $380 \mathrm{~A}$, Core 1 to Hole 380 , Core 36

Hole $380 \mathrm{~A}$, Core 3 to Hole 380 , Core 39 .

According to Schrader, the marine episodes coincide with Traverse's pollen curve where this ratio indicates warm water. However, Traverse and Schrader do not agree on the correlations between Sites 379 and 380 . Jousé and Mukhina note three major marine phases at Site 380 which are essentially the same as that noted by Schrader. The former authors date the Pliocene at the base of Core 31 , Hole $380 \mathrm{~A}$, and the start of the Pontian at Core 55-3, Hole 380A. They distinguish six major diatom assemblages for the site.

For Site 381, Schrader defines nine units and two marine phases (near the surface and Cores 35-38). Jousé and Mukhina noted the latter phase and divide the site into three units.

The authors attempt correlations between the sites. Schrader makes 18 correlations, principally based on species variations due to environmental changes (Table 6). Correlations 5-11 and 13-14 do not fit with Traverse's correlations based on spore and pollen data (Table 4). Jousé and Mukhina's correlations are based on their eight diatoms units. They have also assigned dates to these units, using various paleontological and sedimentological criteria (see Table 7). Schrader also assigns ages to the sediments, but he generally uses sedimentation rates since he feels that no adequate fresh-water diatom stratigraphy is available. I find it extremely difficult to compare the two works because of the differences in nomenclature, i.e., the Waalian or Danube/Ginz can be correlative with the Chauda in one classification (Table 1A) and with the Gurian in another (Table 1B). Unfortunately, there are also considerable differences in the stratigraphy of Jousé and Mukhina (Table 7) and Koreneva and Kartashova (Table 5).

\section{Mollusca}

Several samples containing moliusca were studied by Nevesskaya (this volume). She notes the general absence of shell remains and, where found, the relatively large percentage of juvenile forms (actually only fragments of larger forms were found), and attributed this to the unsatisfactory environmental conditions for benthic life. She is able to give some ages, and notes that Cores $0-5$ from Site 380 (in the “Celia" episode) contains juvenile shells of Dreissena rostriformis and Monodacna caspia which are typical Neoeuxinian brackish water mollusks. In Core 4 she finds juvenile shells of Bittium reticulatum, a characteristic species of both the upper Holocene and the Karangatian horizon. Sample 36 (Site 380 and in the "Anna" episode) has remains of Dreissena and Didacna (?) which can have Paleoeuxinian (Drevneeuxinian) age. These ages are slightly different than those of Kareneva and Kartashova (this volume and Table 5).

\section{Magnetic Stratigraphy}

Magnetic studies on selected samples from Sites 379 and 380 (Hailwood and Hamilton, this volume) have been helpful in establishing some minimal and maximal dates. The Brunhes/Matuyama magnetic epoch boundary (with an age of 700,000 years) can be tentatively assigned to a depth between 145 and 175 
TABLE 6

Stratigraphic Correlations Between Sites Based Primarily on First or Last Occurrences of Diatom Species

\begin{tabular}{|c|c|c|c|c|}
\hline Correlation & $\begin{array}{l}\text { Hole } \\
379 \mathrm{~A}\end{array}$ & $\begin{array}{c}\text { Hole } \\
380\end{array}$ & $\begin{array}{r}\text { Hole } \\
380 \mathrm{~A}\end{array}$ & $\begin{array}{r}\text { Hole } \\
381\end{array}$ \\
\hline $\begin{array}{l}\text { Abundance peak of Stephanodiscus astraea } \\
\text { (correlates with Unit } 2 \text { from piston cores - see } \\
\text { Table 3) }\end{array}$ & - & 1 & - & - \\
\hline Abrupt decrease in $S$. hantzschii & 4 & 4 & - & - \\
\hline Increase in abundance of $S$. hantzschii & 9 & 8 & - & - \\
\hline $\begin{array}{l}\text { Peak abundance of Cyclotella caspia, associated with } \\
\text { Thalassiosira marine species, Chaetoceros species } \\
\text { and absence of Hermesinum adriaticum }\end{array}$ & 11 & $(10(?)$ & - & - \\
\hline $\begin{array}{l}\text { Decrease in abundance of } S . \text { astraea and varieties } \\
\text { and } S \text {. robustus }\end{array}$ & 16 & 15 & - & - \\
\hline $\begin{array}{l}\text { Abundance peak of } S \text {. astraea and varieties and } \\
\text { S. robustus, and one abundance peak of Actino- } \\
\text { cyclus normanii and Cyclotella caspia }\end{array}$ & $\begin{array}{c}18 \\
\text { (tentative) }\end{array}$ & & - & - \\
\hline Abundance peak of $S$. astraea and $S$. robustus & 22 (top) & 31 & - & - \\
\hline $\begin{array}{l}\text { Last abundant occurrence of } A \text {. normannii associated } \\
\text { with Hermesinum adriaticum }\end{array}$ & 24 & 35 & - & - \\
\hline $\begin{array}{l}\text { First abundant occurrence of } A \text {. normannii } \\
\text { associated with } H \text {. adriaticum }\end{array}$ & 25 & 36 & 1 & 1 (Sec. 3) \\
\hline $\begin{array}{l}\text { Decrease in abundance of } A \text {. normannii, increased } \\
\text { S. astraea and its varieties }\end{array}$ & 29 & 39 & 3 & 3 \\
\hline $\begin{array}{l}\text { Abundance peak of } A \text {. normannii and no } \\
\quad \text { H. adriaticum }\end{array}$ & 29 & 39 & $3(?)$ & - \\
\hline $\begin{array}{l}\text { Last occurrence of freshwater diatoms in the lower } \\
\text { Black Sea section }\end{array}$ & - & - & 32 (or 34 ) & 19 \\
\hline $\begin{array}{l}\text { Abundance peak within the range of Melosira } \\
\text { granulata var. angustissima f. curvata, and occurrence } \\
\text { of } S \text {. omarensis and } S \text {. Cyclotella }\end{array}$ & - & - & 38 & 22 \\
\hline $\begin{array}{l}\text { Last common occurrence of } S \text {. carconensis } \\
\quad \text { (triangulate type) }\end{array}$ & - & - & 40 & 26 \\
\hline $\begin{array}{l}\text { First common occurrence of } S \text {. carconensis } \\
\quad \text { (triangulate type) }\end{array}$ & - & - & 42 & 28 (middle part) \\
\hline $\begin{array}{l}\text { Last common occurrence of } S \text {. binderianus type } \\
\text { a. Thalassiosira aff. lineata }\end{array}$ & - & - & 44 & 30 \\
\hline $\begin{array}{l}\text { First common occurrence of } S \text {. binderianus type a, } \\
\text { also the range of Coscinodiscus (?) stokesianus in } \\
\text { Hole } 380 \mathrm{~A} \text { (Cores } 54 \text { to } 51 \text { ) and in Hole } 381 \text { (Cores } \\
34-32 \text { ), the range of Cyclotella operculata }\end{array}$ & - & - & 47 & 32 (bottom) \\
\hline $\begin{array}{l}\text { Last common occurrence of Actinocyclus ehrenbergii, } \\
\text { slightly below common occurrence of } \\
\text { Synedra indica }\end{array}$ & - & - & 55 (top) & 35 (top) \\
\hline
\end{tabular}

meters at Site 379. For Site 380, Core 51 (Hole 380A about $800 \mathrm{~m}$ ) a minimum age of $0.7 \mathrm{~m}$.y. and a maximum age of 2.4 m.y. is estimated (the latter value seems closer to the correct value). These values do not contradict the possible stratigraphies of Tables 4 and 5 , but the maximum age of $2.4 \mathrm{~m}$.y. is stretching Hsü's middle to lower Pliocene estimate for 380 Unit IVb (Table 8). A more detailed investigation should be attempted to define better the magnetic boundaries.

\section{Stratigraphic Correlation Between Sites}

Several of the shipboard scientists met in May of 1976 in an attempt to correlate the sedimentary units described at Sites 379, 380, and 381. The tentative correlations and ages of these sediments are shown in Table 8 . Note especially the use of Roman numerals for Site 380 . Further description of the units can be found in the individual site chapters. Site 380 was described principally by Ken Hsu, whereas Sites 379 and 381 were described principally by Egon Degens and Peter Stoffers. An attempt to assign an age to the Black Sea sediments (by Degens and Stoffers) is also presented on Table 8. These ages are based on estimates of sedimentation rates, changes in the depositional environment and its correlation with neighboring geological events, some paleontological information, and intuition. Again, a careful appraisal of the relevant chapters in this volume should be made by the interested reader. Probably the major difference between the two classifications is that Stoffers and Degens assign an age to the glacial and interglacial events where Hsu uses the glacial and interglacial designations from the pollen and spore work of 
TABLE 7

Correlations, Ages, and Biostratigraphy of Black Sea Sites (adapted from Jousé and Mukhina, this volume)

\begin{tabular}{|c|c|c|c|c|}
\hline Units & & Cores & Age & Comments \\
\hline I & \multicolumn{2}{|c|}{ Piston Cores } & Holocene & Marine diatoms \\
\hline II & $\begin{array}{l}379 \mathrm{~A} \\
380\end{array}$ & $\begin{array}{l}1.4-6, \mathrm{CC} \\
0, \mathrm{CC}-5.3\end{array}$ & Novoeuxinian & Deficient in diatoms \\
\hline III & $\begin{array}{l}379 \mathrm{~A} \\
380\end{array}$ & $\begin{array}{l}7 \mathrm{CC}-11.3 \\
5.3-11, \mathrm{CC}\end{array}$ & Karangat & $\begin{array}{l}\text { Marine diatoms at bottom of section, becoming } \\
\text { fresh towards top }\end{array}$ \\
\hline IV & $\begin{array}{l}379 \mathrm{~A} \\
380\end{array}$ & $\begin{array}{l}11.3-25.1 \\
11-33, \mathrm{CC}\end{array}$ & $\begin{array}{l}\text { Uzunlar and } \\
\text { Paleouzunlar }\end{array}$ & $\begin{array}{l}\text { Mainly fresh-water forms with some brackish and fresh- } \\
\text { water species; changing climate conditions }\end{array}$ \\
\hline $\mathrm{V}$ & $\begin{array}{l}379 \mathrm{~A} \\
380 \\
380 \mathrm{~A} \\
381\end{array}$ & $\begin{array}{l}25.1-30.2 \\
33, \mathrm{CC}- \\
1.1-3.4 \\
1.2-4, \mathrm{CC}\end{array}$ & Drevneeuxinian & Mostly marine species \\
\hline VI & $\begin{array}{l}379 A \\
380 \\
381\end{array}$ & $\begin{array}{l}30.2-? \\
3.4-31, \mathrm{CC} \\
4, \mathrm{CC}-19.5\end{array}$ & Chauda & Mainly terrigenous with no diatoms \\
\hline VII A & $\begin{array}{l}380 \mathrm{~A} \\
381\end{array}$ & $\begin{array}{r}31, \mathrm{CC}-40.4 \\
19.5-26.3\end{array}$ & Pliocene & $\begin{array}{l}\text { Fresh-water diatoms; lake conditions; four diatom } \\
\text { zones are noted }\end{array}$ \\
\hline VII B & $\begin{array}{l}380 \mathrm{~A} \\
381\end{array}$ & $\begin{array}{l}40.4-45, \mathrm{CC} \\
26.3-28.6\end{array}$ & & \\
\hline VII C & $\begin{array}{l}380 \mathrm{~A} \\
381\end{array}$ & $\begin{array}{r}45, \text { CC- } 50.1 \\
28.6-32.2\end{array}$ & & \\
\hline VII D & $\begin{array}{l}380 \mathrm{~A} \\
381\end{array}$ & $\begin{array}{l}50.1-54.1 \\
32.2-34.5\end{array}$ & & \\
\hline VIII & $\begin{array}{l}380 \mathrm{~A} \\
381\end{array}$ & $\begin{array}{l}54.1- \\
34.5-\end{array}$ & $\begin{array}{c}\text { Pontian } \\
\text { (Messinian) }\end{array}$ & Marine \\
\hline
\end{tabular}

Traverse (this volume). The differences can perhaps better be seen by examining the different stratigraphic sections (Figures 1a, 1b). Unfortunately the workers of Site 379 and 381 revised the number system for Site 380 , making meaningful comparisons difficult. A summary of the stratigraphic information is given in Ross (this volume.)

\section{SUMMARY}

A unique and completely acceptable stratigraphy for the drilled Black Sea sediments has not been achieved. This is principally due to different time scales used by various authors, absence of definitive paleontological age markers, and differences in opinion among authors. Thus, appropriate care must be taken in discussing specific aspects of Black Sea stratigraphy. Otherwise, environmental changes of the Black Sea are well documented and generally correlative among the various studies.

\section{ACKNOWLEDGMENT}

This manuscript was reviewed by Drs. Bil Haq and Frank Manheim. The author was supported during the writing of this manuscript by a contract with the Office of Naval Research.

\section{REFERENCES}

Arkhangel'skiy, A.D. and Strakhov, N.M., 1932. Geologicheskoye istoriya Chernogo morya (Geological history of Black Sea): Moskov. Obshch. Ispytateley Piriody Byull., Otdel. Geol. v. 10., p. 3-104.

1938. Geologicheskoye stroyeniye i istoriya razvitiya Chernogo morya (Geological structure and history of evolution of Black Sea): Akad. Nauk SSSR Izv., $226 \mathrm{p}$.

Bukry, D., 1974. Coccoliths as Paleosalinity Indicators-evidence from Black Sea. In Degens, E.T., and Ross, D.A., (Eds.) The Black Sea-geology, chemistry, and biology: Am. Assoc. Petrol. Geol. Mem. 20 , p. $353-363$.

Degens, E.T. and Ross, D.A. (Eds.), 1974. The Black Sea-geology, chemistry, and biology: Am. Assoc. Petrol. Geol. Mem. 20, 633 p.

Federov, P.V., 1956. O sovremennoi epokhe v geologicheskom istorii Chernogo morya (Modern epoch in geological history of Black Sea): Akad. Nauk SSSR Doklady, v. 110 , p. 839-841.

, 1963. Stratigrafiya obetvertichnykh osloshenii Krymskogo-Kavkazkogo poberzh'ya i nekotorye voprosy geologicheskoy istorii Chernogo morya (Stratigraphy of Quaternary sediments on coast of Crimea and Caucasus and some other problems connected with the geological history of the Black Sea): Akad. Nauk SSSR Geol. Inst. Trudy, v. 88, p. 7-159; National Lending Library RTS No. 2572,245 p.

Markov, K.K., Lazukov, G.I. and Nikolayev, V.A., 1965. The Quaternary Period (Glacial period-Antropogen period), v. 1: The Territory of the USSR: Moscow (Moskov. Univ.), $371 \mathrm{p}$.

Nevesskaya, L.A., 1965. Pozdnechetvertichnye dvustvorchatye mollyuski Chernogo morya, ikh sistematika i ekologiya (Late Quaternary bivalve molluscs of the Black Sea, their systematics and ecology): Akad. Nauk SSSR Paleont. Inst. Trudy, v. 105. p. 1-390.

Nevesskii, Ye.N., 1961. O poslelednikovoi transgressii Chernogo morya, Akad. Nauk SSSR Doklady, v. 137, no. 3, p. 667-670; Engl. transl., 1962, Post-glacial transgression of the Black Sea: Am. Geol. Inst., v. 137, p. $317-320$. 
van Eysinga, F.W.B., 1975. Geological time table, 3rd Ed.: Netherlands (Elsevier Publ Co.)

Wall, D. and Dale, B., 1974. Dinoflagellates in late Quaternary deep-water sediments of Black Sea. In Degens,
E.T., and Ross, D.A., (Eds.), The Black Sea-geology, chemistry, and biology: Am. Assoc. Petrol. Geol. Mem. 20 , p. $364-380$.

TABLE 8

Tentative Correlation of Sites 379,380 , and 381

Based on Post-Cruise Meeting

\begin{tabular}{|c|c|c|}
\hline $\begin{array}{c}\text { Hsü } \\
(380)\end{array}$ & $\begin{array}{l}\text { Stoffers and Degens } \\
\quad(379 \text { and 381) }\end{array}$ & $\begin{array}{l}\text { Tentative Age } \\
\text { (see text) }\end{array}$ \\
\hline $\mathrm{I}_{\mathrm{a}}$ and $\mathrm{I}_{\mathrm{b}}$ & $1 \& 2$ (379) & Holocene \\
\hline $\mathrm{I}_{\mathrm{c}}$ & $3(379)$ & Weichselian/Würm \\
\hline$I_{d}$ & $4 \& 5(379)$ & Eemian/Riss-Würm Interglacial \\
\hline $\mathrm{I}_{\mathrm{e}}$ & $6(379)$ & $\begin{array}{l}\text { Saalian/Riss (Stoffers and Degens) } \\
\text { Glacial and Interglacial (Hsü) }\end{array}$ \\
\hline $\mathrm{I}_{\mathrm{f}}$ & $7(379)$ & $\begin{array}{l}\text { Holsteinian (Stoffers and Degens) } \\
\text { Interglacial B (Hsü) }\end{array}$ \\
\hline $\left.\begin{array}{l}\mathrm{I}_{\mathrm{g}} \\
\mathrm{I}_{\mathrm{h}}\end{array}\right\}$ & $8(379)$ & $\begin{array}{l}\text { Elster/Mendel (Stoffers and Degens) } \\
\text { Glacial B (Hsü) }\end{array}$ \\
\hline II & $\begin{array}{r}9 \& \text { Deeper } \\
\text { (379) }\end{array}$ & About 800,000 (Stoffers and Degens) \\
\hline II \& III & $9(379)$ & Plio/Quat (Hsü) \\
\hline III & $2(381)$ & $\begin{array}{c}\text { Eburon (cold period about } \\
1.7 \times 10^{6}-\text { Stoffers and Degens) }\end{array}$ \\
\hline III & $\begin{array}{l}\text { Part of } 9(379) \text { and } \\
2(381)\end{array}$ & $\begin{array}{c}\text { Alpha (glacial - about } 2 \times 10^{6} \\
\text { Hsü) }\end{array}$ \\
\hline $\mathrm{IV}_{\mathrm{a}}$ & $3(381)$ & $\begin{array}{c}\text { Tiglian }\left(2.2 \times 10^{6} \text { base }- \text { Stoffers and }\right. \\
\text { Degens) U. Pliocene (Hsũ) }\end{array}$ \\
\hline $\mathrm{IV}_{\mathrm{b}}$ & $4(381)$ & $\begin{array}{l}\text { Pretiglian (Stoffers and Degens) } \\
\text { M.-L. Pliocene (Hsü) }\end{array}$ \\
\hline $\mathrm{IV}_{\mathrm{c}}$ & $5(381)$ & $\left\{\begin{array}{c}\text { About } 2.6 \times 10^{6} \text { or younger } \\
\text { (Stoffers and Degens) } \\
\text { L. Pliocene (Hsü) }\end{array}\right.$ \\
\hline $\mathrm{IV}_{\mathrm{d}, \mathrm{e}} \& \mathrm{~V}_{\mathrm{a}}$ & $6(381)$ & $\begin{array}{c}\text { Pliocene (or possibly older - Stoffers } \\
\text { and Degens) }\end{array}$ \\
\hline $\mathrm{IV}_{\mathrm{d}}$ & $6,7,8$ & L. Miocene (Hsü) \\
\hline $\mathrm{v}_{\mathrm{b}}$ & $\begin{array}{l}\text { Uncored Zeolite } \\
\text { Interval }\end{array}$ & Pliocene? (Stoffers and Degens) \\
\hline $\mathrm{IV}_{\mathrm{e}}+\mathrm{V}_{\mathrm{a}}$ & 9 & Miocene (Hsü) \\
\hline $\begin{array}{l}>V_{b} \\
>V_{b} \\
>V_{b}\end{array}$ & $\begin{array}{l}7 \\
8 \\
9\end{array}$ & $\left\{4-5 \times 10^{6}\right.$ (Stoffers and Degens) \\
\hline
\end{tabular}




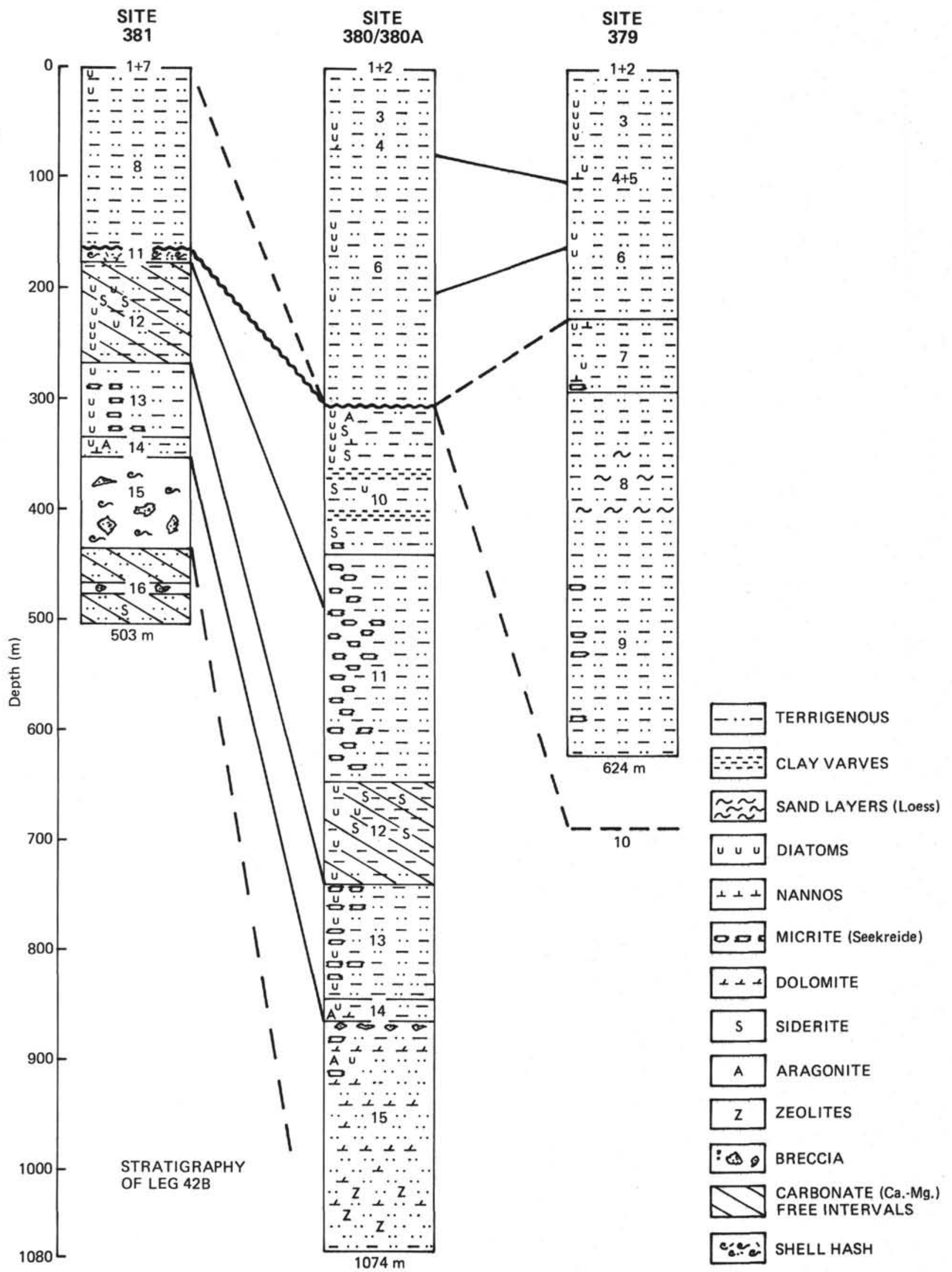

Figure 1a. Stratigraphic section from Stoffers et al., this volume. 


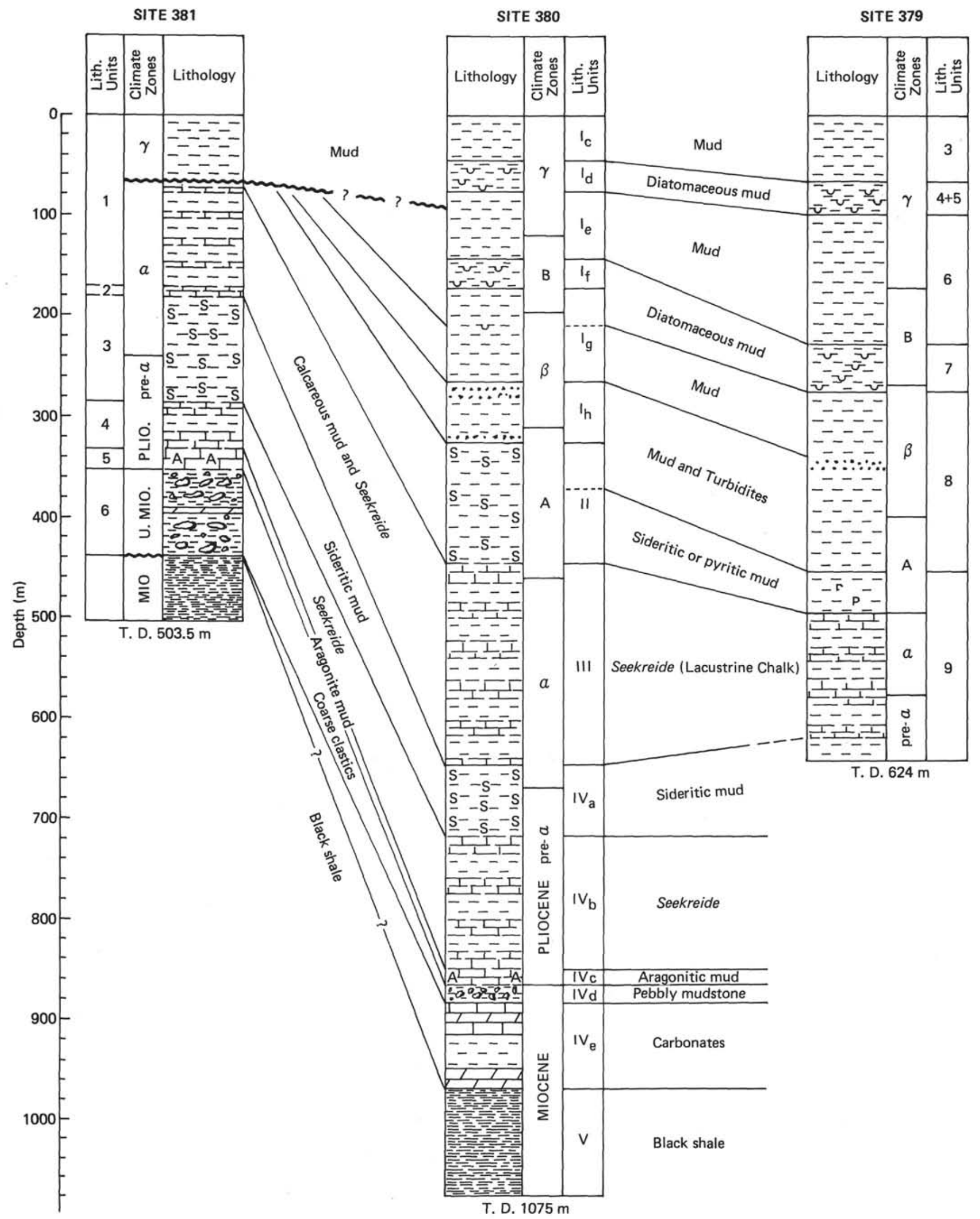

Figure 1b. Stratigraphic section from Hsü, this volume. 